\title{
PERAN PANTI ASUHAN DALAM MENANAMKAN PENDIDIKAN KARAKTER ANAK ASUH
}

\author{
Osy Afriani, M. Salam, \& Heri Usmanto \\ Prodi PPKn FKIP Universitas Jambi, Jambi \\ Email: Osyafriyani24@gmail.com
}

\begin{abstract}
Abstrak
Hasil observasi awal menunjukan adanya beberapa karakter anak asuh yang masih belum sesuai dengan nilai religius dan nilai gotong royong yang diharapkan. Tujuan penelitian ini adalah mendeskripsikan upaya serta faktor pendukung dan penghambat dalam menanamkan pendidikan karakter pada nilai religius dan gotong royong. Desain penelitian ini menggunakan metode kualitatif deskriptif dengan pengumpulan data yang digunakan yaitu wawancara, observasi, dokumentasi. Berdasarkan analisis data menggunakan reduksi, penyajian data, penarikan kesimpulan. Hasil penelitian menunjukan bahwa peran Panti Asuhan Taman Bina Insany dalam upaya menanamkan pendidikan karakter pada nilai religius dan gotong royong melalui program-program, aturan, metode, sanksi yang dapat mengembangkan karakter religius dan gotong royong anak asuh. Analisis serta Kesimpulan hasil penelitian ini ialah Peran panti asuhan dalam menanamkan pendidikan karakter pada nilai religius dan gotong royong anak asuh dengan memberikan pelayanan kuratif dan rehabilitatif. Adapun dalam upaya penanaman pendidikan karakter dipengaruhi oleh faktor pendukung dan faktor penghambatnya.
\end{abstract}

Kata Kunci: Panti asuhan, Pendidikan karakter Anak Asuh, Nilai Religius, Nilai Gotong royong.

\begin{abstract}
The results of initial observations show that there are severaln characters of foster children who are stiil not in accordance with religious values and mutual cooperation values the expected. . The purpose this study is to describe the efforts as well as the supporting and inhibiting factors in instilling character education in religious values and integrity. This research design uses a qualitative method with case study approach with data collection used, namely interviews, observations, documentation. Based on data analysis using reduction, data presentation, conclusion drawing. The results showed that the role of the Taman Bina Insany Orphanage in an effort to instill character education in religious values and integrity is through programs, rules, methods, sanctions that develop the religious character and integrity. The analysis and conclusion of this research is the rolle of orphanages in instiking character education in religious values and the value of mutual cooperation by providing curative ang rehabilitative, this is also influenced by supporting factors and inhibiting factors.
\end{abstract}

Keywords: Orphanage, Foster Children's Character Education, Religious Values, Integrity Values

\section{PENDAHULUAN}

Anak ialah generasi penerus bangsa yang memiliki peran strategi sebagai pemegang ujung tombak kemajuan bangsa yang akan datang. Kelangsungan bangsa pada masa yang akan tergantung pada kualitas pertumbuhan mereka.

Pendidikan karakter merupakan pendidikan yang mengutamakan esensi dan makna terhadap moral dan akhlak sehingga mampu membentuk pribadi yang baik. Pendidikan karakter memerlukan proses secara sistematis dan sesuai dengan fase pertumbuhan dan perkembangan anak (Abdul, dkk 2012: 23).

Dalam konsep dan pedoman penguatan pendidikan karakter yang disusun oleh kementerian pendidikan dan kebudayaan revisi 2017 ada lima nilai utama karakter yang saling berkaitan membentuk jejaring nilai yang perlu dikembangkan sebagai prioritas Gerakan PPK, yaitu nilai religius, nilai nasionalisme, nilai integritas, nilai mandiri dan nilai gotong royong (Sakinah \& Dewi, 2021). 
Di Indonesia tentang pasal pendidikan telah dilaksanakan dalam UUD pasal 31 tentang warga negara untuk memperoleh pendidikan termasuk di dalamnya anak yatim, piatu dan yatim piatu yang berada di panti asuhan. Pendidikan yang dimaksud di dalamnya ialah termasuk salah satunya ialah pendidikan karakter. Pengertian panti asuhan menurut Depsos RI (2004:4), panti asuhan anak ialah lembaga usaha kesejahteraan sosial yang memiliki tanggung jawab dalam memberikan pelayanan kesejahteraan sosial untuk anak-anak terlantar dengan melakukan penyantunan dan pengentasan anak terlantar, memberikan pelayanan pengganti orang tua/wali anak dalam memenuhi kebutuhan fisik, mental maupun sosial kepada anak asuh sehingga anak asuh bisa memperoleh kesempatan yang luas, tepat dan memadai guna pengembangan kepribadiannya sesuai dengan yang diharapkan yaitu sebagai bagian dari generasi penerus cita-cita bangsa dan sebagai insan yang akan turut serta aktif dalam bidang pembangunan Nasional (Dewantara \& Nurgiansah, 2021a).

Menurut T. Ramli (2003) penanganan dalam masalah kesejahteraan sosial anak terlantar melalui sistem panti merupakan dimana pola asuhan diberikan kepada anak-anak yang terlantar. Pelayanan yang diberikan ialah berupa penyediaan fasilitas pemenuhan kebutuhan sandang, pangan, pendidikan, bimbingan rohani dan keterampilan, diharapkan anak-anak tersebut mampu mengembangkan pribadi, potensi, kemampuan serta minatnya secara optimal. Pendidikan yang dimaksud di dalamnya termasuk pendidikan karakter (Winda, 2016:85).

Panti Asuhan Taman Bina Insany ialah salah satu lembaga panti asuhan yang berada di provinsi Jambi yang beralamat di Kelurahan Murni Kecamatan Danau Sipin Kota Jambi. Salah satu misi dan visi Panti Asuhan Taman Bina Insany adalah
Terbinanya generasi potensial yang cerdas secara emosional, mandiri, memiliki jiwa sosial yang tinggi, Memiliki life skill sehingga mampu menjawab setiap tantangan zaman. Mencetak Sumber Daya Manusia (SDM) yang akademis, mampu menciptakan karya baru, dan dapat mengabdikan diri terhadap agama dan bangsa.

Tabel 1.1 Karakter Anak Asuh di Panti Asuhan Taman Bina Insani

\begin{tabular}{|c|c|c|c|c|c|}
\hline $\begin{array}{c}\text { Nilai } \\
\text { Karakter }\end{array}$ & $\begin{array}{c}\text { Indikator/Sik } \\
\text { ap Yang } \\
\text { Diamati } \\
\end{array}$ & $\begin{array}{l}\text { M } \\
\text { B }\end{array}$ & B & $\begin{array}{c}\text { MB } \\
\mathbf{K}\end{array}$ & $\begin{array}{l}\text { M } \\
\mathbf{B}\end{array}$ \\
\hline \multirow[t]{4}{*}{ Religius } & $\begin{array}{l}\text { ketaatan } \\
\text { beribadah/Me } \\
\text { njalankan } \\
\text { kegiatan } \\
\text { ibadah dan } \\
\text { perayaan } \\
\text { kegamaan }\end{array}$ & 14 & 1 & 0 & 0 \\
\hline & $\begin{array}{l}\text { Menerapkan } \\
\text { ajaran } \\
\text { agama/membe } \\
\text { ri salam sapa }\end{array}$ & 13 & 1 & 0 & 1 \\
\hline & $\begin{array}{l}\text { berbuat } \\
\text { kebaikan/hidu } \\
\text { p rukun }\end{array}$ & 1 & $\begin{array}{l}1 \\
2\end{array}$ & 1 & 1 \\
\hline & $\begin{array}{l}\text { Toleransi/men } \\
\text { ghargai } \\
\text { perbedaan } \\
\text { agama dengan } \\
\text { orang lain }\end{array}$ & 10 & 3 & 1 & 1 \\
\hline \multirow[t]{4}{*}{$\begin{array}{l}\text { Gotong } \\
\text { Royong }\end{array}$} & $\begin{array}{l}\text { Kerja } \\
\text { sama/Berparti } \\
\text { sipasi dalam } \\
\text { kegiatan } \\
\text { bersama untuk } \\
\text { menyelesaikan } \\
\text { sebuah tugas }\end{array}$ & 13 & 2 & 0 & 0 \\
\hline & $\begin{array}{l}\text { Komunikatif/ } \\
\text { Meminta dan } \\
\text { memberikan } \\
\text { pendapat }\end{array}$ & 6 & 4 & 5 & 0 \\
\hline & $\begin{array}{l}\text { Tolong } \\
\text { menolong }\end{array}$ & 9 & 6 & 0 & 0 \\
\hline & $\begin{array}{l}\text { Sosialisasi/me } \\
\text { njalin } \\
\text { pertemanan } \\
\text { dengan orang } \\
\text { lain }\end{array}$ & 10 & 0 & 5 & 0 \\
\hline
\end{tabular}

(Sumber: data olahan daftar pertanyaan anak asuh Panti Asuhan Taman Bina Insani, 2021)

Keterangan: 


$$
\begin{array}{ll}
\text { MB } & \text { : Membudidaya } \\
\text { B } & \quad \text { : Berkembang } \\
\text { MBK } & \text { : Mulai Berkembang } \\
\text { MB } & \text { : Memerlukan Bimbingan }
\end{array}
$$

Setelah melakukan observasi awal dan pertanyaan singkat/survey yang diajukan kepada 15 anak asuh dari 116 anak asuh terlihat pada tabel 1.1 dalam penanaman pendidikan karakter pada nilai religius dan nilai gotong royong di Panti Asuhan Taman Bina Insany sudah diupayakan namun masih ada beberapa karakter anak asuh yang belum sesuai dengan nilai-nilai yang diharapkan. Diketahui bahwa dari nilai religius anak asuh yaitu salam sapa, hidup rukun dan toleransi belum tertanam pada beberapa anak asuh, masih sering terjadi pertengkaran serta dalam mengembangkan sikap toleransi yang terlihat masih sangat memerlukan bimbingan karena di panti asuhan itu sendiri terdiri dari satu agama yang mayoritas islam. Sedangkan dalam nilai gotong royong masih ada beberapa karakter anak asuh yang masih harus terus dibimbing terutama dalam karakter komunikatif, sosialisasi/persahabatan (Rachman et al., 2021).

Dan berdasarkan wawancara awal kepada Pembina dan anak asuh diketahui kesulitan panti asuhan dalam menanamkan pendidikan karakter disebabkan oleh beberapa kendala yang dihadapi diantaranya minimnya Sumber Daya Manusia (SDM), sarana dan prasarana yang tentu berpengaruh terhadap pengelolaan tujuan yang diharapkan dan sampai sekarang masih terus dalam proses perbaikan. Dan adapun pelaksanaan pendidikan karakter didukung dengan basic agama sebagai nilai utama dalam pendidikan kaarakter yang diharapkan dapat megajarkan/membiasakan anak asuh menjalankan ibadah ataupun ajaranajaran agama ataupun nilai-nilai baik dalam kehidupan.

Generasi muda merupakan generasi harapan bangsa, untuk melaksanakan pendidikan karakter sebagai lemabga nonformal yang memiliki salah satu peran untuk membentuk karakter anak, maka perlu adanya upaya dari berbagai elemen salah satunya dapat dilihat dari panti asuhan anak. Dengan jumlah panti asuhan yang tidak sedikit, tentu artinya ada banyak penerus bangsa yang menjadi tanggung jawab lembaga panti asuhan untuk memberikan pelayanan pendidikan karakter. Maka perlu pengurusan dan strategi yang baik agar menghasilkan anakanak yang baik pula.

Karakter merupakan kulminasi dari kebiasaan yang dihasilkan dari perilaku dan sikap yang dimiliki seorang individu yang telah menjadi moral yang melekat dan menyatu dengan kepribadian seseorang sebagai tindakan atas dorongan hati dan pikiran (Eko, 2018:25) (Dewantara \& Nurgiansah, 2021b). Jadi misi pendidikan karakter sama dengan pendidikan akhlak atau pendidikan moral. Salah satu teorinya ialah teori psikoanalitik, teori ini bersumber dari ajaran Sigmund Freud yang memandang hakikat manusia sebagai makhluk yang dikendalikan oleh hati nurani dan dipengaruhi oleh keadaan disekitarnya (Super Ego). Dalam membentuk perilaku dan moral anak yang melekat dengan kepribadiannya (karakter) dikendalikan oleh Id, Ego, dan Super ego. Id adalah sesuatu dalam diri seorang atau insting yang berisi dorongan untuk berperilaku mengikuti nafsu, Ego merupakan bagian dari kepribadian penentu terbentuknya perilaku riil, sedangkan Super Ego ialah lingkungan dan agen pengendali yang menjembatani dan memberi pertimbangan kepada individu untuk berperilaku (Sjarkawi, 2006:48).

Adapun penjelasan lebih luas yang berkaitan dengan isi teori psikoanalitik menurut Zubaedi (2012:177-183) faktorfaktor yang dapat mempengaruhi keberhasilan ataupun kegagalan dalam penanaman pendidikan karakter ialah sebagai berikut: 
1. Insting (Naluri)

Insting merupakan tabiat yang dibawa sejak lahir dan suatu pembawaan yang asli atau corak sikap, tindakan, dan perbuatan manusia dimotivasi oleh potensi kehendak dan dimotori oleh naluri seseorang.

Dalam konsep freud, naluri atau insting adalah rangsangan pada manusia sehingga munculnya kebutuhan. Dan sesuai dengan konsep psikoanalisis bahwasanya manusia adalah makhluk yang mempunyai keinginan dan kebutuhan dasar untuk terus berkembang menjadi lebih baik.

2. Kebiasaan/adat

Kebiasaan merupakan suatu tindakan yang dilakukan secara berulang-ulang dalam bentuk yang sama sehingga secara tidak langsung dapat membentuk karakter seseorang.

3. Keturunan

Sifat-sifat yang dimiliki anak sebagian besar adalah sifat-sifat pantulan/pewarisan dari orang tua anak, baik sifat jasmaniah maupun sifat rohaninya. Peranan keturunan juga dikenal pada suku, bangsa dan daerah seseorang.

4. Lingkungan

Lingkungan ialah segala sesuatu di sekitar manusia yang melingkupi hidup manusia yang mengelilinginya, mulai dari lingkungan fisik hingga pada lingkungan sosial. Lingkungan fisik yang dimaksud disini ialah fasilitas atau sarana dan prasarana sebagai penunjang dalam pembentukan karakter anak yang mempengaruhi dalam upaya penanaman pendidikan karakter.

Dalam 5 nilai utama Penguatan Pendidikan Karakter, dapat dilihat pada tabel karakter anak asuh 1.1 hasil survey yang telah dilakukan di panti asuhan taman bina insani, nilai gotong royong ialah nilai yang paling sedikit tingkat keberhasilannya, serta nilai religius yang merupakan pondasi utama dalam mendukung nilai-nilai pendidikan karakter lainnya (Nurgiansah, 2021a). Dengan demikian penelitian ini berfokus dengan peran panti asuhan dalam menanamkan pendidikan karakter pada nilai religius dan nilai gotong royong anak asuh di Panti Asuhan Taman Bina Insani

Dalam gerakan PPK (Penguatan Pendidikan Karakter) yang merupakan 5 kristalisasi dari nilai-nilai utama karakter tersebut adalah nilai religius, nasionalisme, mandiri, integritas, gotong royong. Adapun sesuai dengan fokus masalah penelitian penjelasan pada nilai religius dan nilai gotong royong adalah sebagai berikut:

a. Nilai religius

Menurut Mustari (2014: mengemukakan bahwa karakter religius ialah nilai yang berkaitan dengan tuhanNya yang menggambarkan pikiran, perbuatan dan perkataanya berlandaskan pada nilai-nilai ajaran agama. Ngaunun Naim (2012: 124) berpendapat bahwa nilai religius ialah penerapan/implementasi ajaran agama dalam kehidupan sehari-hari. Maka disimpulkan nilai religius ialah nilai yang menanamkan ajaran-ajaran agama dalam diri seseorang.

Adapun indikator ataupun sikap yang dapat peneliti amati pada tingkat usia anak setara dengan jenjang pendidikan SLTP/SLTA menurut model penilaian karakter yang diterbitkan pada tahun 2017 dari KEMENDIKBUD yaitu melaksanakan ibadah dan menjalankan kegiatan perayaan kegamaan, menjalankan ajaran agama dalam bersikap sopan santun/saling sapa, berbuat kebaikan/cinta damai dan hidup rukun dengan orang lain, toleransi kepada pemeluk agama lain.

b. nilai gotong royong

Nilai gotong royong ialah suatu nilai yang menggambarkan usaha bersama, suatu amal, suatu pekerjaan atau hasil karya bersama dan suatu perjuangan saling 
bantu-membantu (Effendi, 2013:5). Adapun penegertian gotong royong ialah kerja sama, semangat dalam persaudaraan, saling membantu dan tolong-menolong untuk kebaikan bersama (Panjaitan, 2106:36). Maka dapat disimpulkan bahwa nilai gotong royong ialah sikap yang menunjukan seseorang yang memiliki jiwa kooperatif, mementingkan kepentingan bersama dan menjujung tinggi hasil musyawarah untuk kebaikan bersama.

Adapun indikator ataupun sikap yang dapat peneliti amati pada tingkat usia anak setara dengan jenjang pendidikan SLTP/SLTA menurut model penilaian karakter yang diterbitkan pada tahun 2017 dari KEMENDIKBUD yaitu kerja sama, komunikatif (dapat menyampaikan dan menerima pendapat orang lain), Saling tolong-menolong, sosialisasi (dengan menjalin pertemanan/persahabatan dengan orang lain).

Setiap manusia perlu melakukan pembangunan karakter. Seperti menurut Ellen G. White menyatakan bahwa pembangunan karakter merupakan proses/usaha yang penting dilakukan oleh manusia yang merupakan tujuan yang besar dari sebuah sistem pendidikan yang benar (Syamsul, 2016:31) (Nurgiansah, 2020). Dengan demikian pendidikan karakter sangat penting dalam mengembangkan kemampuan diri sehingga menjadi pribadi yang unggul dan bermoral di tengah masyarakat dengan tingginya multikulturalisme serta meningkatkan kepribadian dan identitas yang unggul dan kompetitif.

Diharapkan dengan pendidikan karakter dapat menghasilkan pribadi yang unggul, bukan hanya mempunyai kemampuan kognitif saja melainkan memiliki karakter yang dapat menunjang kesuksesan anak. Dimana dengan pelayanan yang diberikan kepada anak asuh di panti asuhan seperti pemenuhan fasilitas, sandang dan pangan, pendidikan, pembinaan keterampilan, jasmani dan rohani diharapkan dapat memperbaiki, mengembangkan potensi pribadi serta kemampuan dan minat anak dengan optimal.

Hal ini sesuai dengan hasil penelitian Winda Anggunita yang berjudul "peran lembaga kesejahteraan anak dalam menanamkan pendidikan karakter terhadap anak asuh di panti asuhan" yang menyatakan bahwa Persoalan pendidikan karakter secara umum juga disebut dengan pendidikan moral, sejauh ini implementasi pendidikan karakter hanya terfokus pada satu arah pembelajaran khusus dalam bentuk sudut kurikulum (Nurgiansah, 2021b). Pendidikan karakter itu sendiri penting diimplementasikan dalam lembaga sosial/panti asuhan. Penanaman pendidikan karakter menjadi dasar dalam pembentukan karakter yang berkualitas.

Dengan jumlah panti asuhan yang tidak sedikit maka perlu perhatian khusus adanya pembaharuan pendidikan karakter yang diharapkan dalam meningkatkan kualitas pendidikan karakter pada panti asuhan seperti yang di kemukakan oleh Misbah (1978) yaitu:

1. Masalah pemerataan Pendidikan, karena setiap anak memiliki hak dalam pendidikan (termasuk di dalamnya pendidikan karakter), karena panti asuhan merupakan peran pengganti dalam keluarga dalam membentuk karakter anak asuh.

2. Masalah relevansi pendidikan dengan tuntunan masyarakat

3. Masalah kualitas/mutu pendidikan di panti

4. Masalah efisiensi pendidikan karakter pada anak panti.

Pendidikan karakter di lembaga sosial/panti asuhan dapat terimplementasikan dengan baik jika faktor yang mempengaruhi pendidikan karakter mendukung, seperti naluri pada seseorang, kebiasaan, keturunan maupun lingkungan sosial atau lingkungan fisik 
(sarana dan prasarana). Pendidikan karakter mengupayakan memaksimalkan potensi karakter yang positif yang menjadi dasar modal pengembangan individu dan bangsa.

Berlandaskan penjelasan masalah yang telah diuraikan diatas, peneliti tertarik melakukan penelitian lebih jauh mengetahui bagaimana peran panti asuhan dalam mengupayakan penanaman pendidikan karakter, faktor pendukung dan penghambat penanaman pendidikan karakter dengan judul "Peran Panti Asuhan Dalam Menanamkan Pendidikan Karakter Anak Asuh (Studi Kasus Panti Asuhan Taman Bina Insani Di Kelurahan Murni Kecamatan Danau Sipin Kota Jambi)”.

\section{METODE PENELITIAN}

Penelitian ini dilakukan di Panti Asuhan Taman Bina Insani di Jalan Sultan Agung, No 76, RT. 14, Kelurahan Murni, Kecamatan Danau Sipin Kota Jambi. Dalam merancang riset penelitian ini.

Data dan sumber data penelitian diperoleh dari informan yaitu ketua, pembina/pengurus panti asuhan taman bina insani, guru PPKn yayasan tarbiyah mazniyah serta dua orang anak asuh yang ditentukan dengan teknik purposive sampling. Dan adapun sumber data yang diperoleh yaitu aktivitas/kegiatan di panti asuhan taman bina insani dengan teknik pengumpulan data berupa wawancara, observasi dan dokumentasi. Teknik wawancara yang dilakukan dengan menggunakan in-depth interview, sedangkan dalam teknik observasi peneliti menggunakan observasi partisipatif yaitu peneliti berinteraksi dengan anggota panti asuhan, berpartisipasi dalam aktivitas mereka mempelajari perilaku mereka dan memperoleh data terkait upaya penanaman pendidikan karakter serta faktor pendukung dan penghambat dalam menanamkan pendidikan karakter yang terfokus pada nilai religius dan nilai gotong royong.
Adapun teknik dalam pengumpulan data yang dilakukan adalah reduksi data, penyajian data dan penarikan kesimpulan. Dalam uji kredibilitas data hasil penelitian, menurut Sugiyono (2012:270) uji kredibilitas data atau kepercayaan data hasil penelitian dapat dilakukan dengan salah satu uji validitas triangulasi yaitu dengan peneliti melakukan pengecekan data dari berbagai sumber, berbagai cara, dan berbagai waktu.

\section{HASIL PENELITIAN DAN PEMBAHASAN Hasil Penelitian \\ Upaya penanaman pendidikan karakter pada nilai religius dan nilai gotong royong di Panti Asuhan Taman Bina Insani}

Dengan penelitian yang dilakukan di Panti Asuhan Taman Bina Insani hasil penelitian menunjukan bahwa upaya dalam menanamkan pendidikan karakter pada nilai religius dan nilai gotong royong sudah dilaksanakan, dengan teknik pengumpulan data yang dilakukan dan dapat diketahui bahwasanya dalam upaya menanamkan pendidikan karakter anak dalam aspek nilai religius dan aspek nilai gotong royong sebagai berikut;

a. aspek nilai religius

Dalam menanamkan pendidikan karakter religius pada aspek yang diamati yaitu: melaksanakan sholat dan ibadah lainnya, salam sapa/sopan santun dan cinta damai. Upaya yang dilakukan Panti Asuhan Taman Bina Insani ialah Pertama, memaksimalkan aturan-aturan/program yang telah disepakati. Panti Asuhan Taman Bina Insany memiliki aturan-aturan terkait penanaman nilai-nilai religius. Dengan aturan-aturan yang telah dibuat harapannya dapat memberikan pendidikan dan penanaman nilai religius, aturanaturan/program yang di terapkan tersebut ialah menggunakan jilbab untuk perempuan saat berada di luar asrama ataupun di depan nonmahram, melaksanakan sholat berjamaah dan 
mengaji, adapun program tahfidz yang dilaksanakan dua kali dalam seminggu, yaitu pada hari sabtu dan minggu. Dan adapun salam sapa/sopan santun yaitu dengan menggunakan 3S (Salam, Senyum, Sapa) ketika bertemu orang lain. Dan adapun memperingati peryaan hari-hari besar islam yang dilakukan yaitu isra' mi'raj dan maulid Nabi.

Dalam kehidupan sehari-hari bapak/ibu pembina panti juga selalu membiasakan atau mencontohkan aturanaturan yang telah disepakati, walaupun masih ada beberapa anak yang masih belum bisa melaksanakan program/aturan yang telah dibuat. Begitu juga beberapa anak masih jarang untuk menerapkan 3S (Salam, Senyum, Sapa), karena masih merasa malu ketika harus berkomunikasi dengan orang baru, artinya upaya penanaman ini sedikit demi sedikit dapat melekat pada anak asuh meskipun dalam proses yang cukup lama. Adapun anak asuh yang sebelumnya jarang membuka AlQuran kini menjadi lebih sering. Begitu juga dengan salam sapa/sopan santun, beberapa anak asuh sudah mulai menerapkannya, ini tergantung lamanya anak asuh tinggal di panti. Sedangkan untuk mengembangkan sikap toleransi dalam kaitan hubungan antara agama belum ada kegiatan khusus karena Panti Asuhan Taman Bina Insany merupakan satu agama yang mayoritas islam.

Melalui peraturan/program yang telah dibuat anak asuh menjadi lebih tertib, terkontrol dan dapat menanggulangi masalah-masalah karakter pada nilai religius anak asuh menjadi lebih baik. Upaya ini dapat dilihat dari hasil wawancara dengan ibu pembina dan ketua panti asuhan yang dapat disimpulkan bahwa perubahan kebiasaan anak asuh yang sebelumnya jarang melaksanakan sholat dan sikap sopan santun hingga kini setelah masuk panti asuhan menjadi lebih terbiasa.
Kedua, upaya selanjutnya yang dilakukan panti asuhan ialah dengan memberikan sanksi dengan tujuan pembinaan kepada anak asuh yang telah melakukan kesalahan atau pelanggaran aturan-aturan dalam proses penanaman pendidikan religius karakter anak asuh. Contohnya ketika anak asuh tidak melaksanakan sholat, tidak mengikuti program tahfidz, terlibat perkelahian antar anak asuh maka ada sanksi yang diberikan, berupa hukuman membersihkan lingkungan panti, jalan jongkok, lari mengelilingi lapangan. Tujuan dari pemberian sanksi ini merupakan memberikan efek jera kepada anak asuh sehingga anak asuh tidak mengulangi kesalahan dan pelanggaran tersebut dan membiasakan pada perbuatan-perbuatan yang mencerminkan nilai religius.

Ketiga, melakukan upaya memberi pemahaman kepada anak asuh dengan penyampaian teori/ceramah, metode pembiasaan dan metode keteladanan. Cara panti asuhan mendisiplinkan anak asuh melalui nasehat yang di berikan ketika selesai kegiatan bersama. Selain itu pembina panti asuhan juga menegur secara langsung, memberi arahan disertai sanksi agar anak asuh tidak mengulang kembali pelanggaran. Selain itu pengurus panti juga menerapkan metode pembiasaan dan keteladanan, namun lebih sering menggunakan metode penyampaian teori/ceramah. Metode pembiasaan tersebut sejalan dengan upaya penerapan aturan ataupun kegiatan-kegiatan yang sudah dibuat agar anak terbiasa melakukan hal-hal positif sesuai dengan yang diharapkan. Sedangkan metode keteladanan dilakukan pengurus dengan menjadi role model atau mencontohkan secara langsung kepada anak asuh untuk berperilaku baik sesuai dengan nilai-nilai karakter yang diharapkan, seperti 3S (Salam, Senyum, Sapa), melaksanakan ibadah sesuai tuntunan agama dan cinta damai serta toleransi. 
b. Aspek Nilai Gotong royong

Dalam menanamkan pendidikan karakter gotong royong pada sikap yang diamati yaitu: kerja sama, komunikatif, tolong menolong dan sosialisasi/persahabatan. Upaya yang dilakukan Panti Asuhan Taman Bina Insany. Pertama, ialah dengan memberikan kegiatan yang dapat mengembangkan karakter pada nilai gotong royong anak asuh di Panti Asuhan Taman Bina Insany, Seperti tugas dan jadwal yang telah di buat yaitu tugas memasak, piket kebersihan asrama, aula dan ruang lainnya yang dilakukan secara bergantian. Disini anak asuh dididik untuk membangun kerja sama, bersosialisasi, serta tolong menolong. Adapun jadwal piket lainnya seperti piket kebersihan asrama, aula dan ruang lainnya yang biasanya dilakukan secara bersama-sama pada hari sabtu dan minggu.

Dengan demikian diharapkan agar anak asuh kedepannya memiliki karakter yang kooperatif dalam menjalankan wewenang/tugas yang sudah diberikan. Selanjutnya membiasakan anak asuh dengan jadwal harian yang memang disusun tidak berdasarkan tingkat sekolah dan umur agar anak asuh bisa saling berbaur dan dapat membangun persahabatan satu sama lain.

Kedua, upaya selanjutnya yang dilakukan panti asuhan ialah dengan memberikan sanksi/hukuman dengan tujuan pembinaan kepada anak asuh yang telah melakukan kesalahan atau pelanggaran aturan-aturan dalam proses penanaman pendidikan karakter pada nilai gotong royong. Untuk anak asuh yang telah melanggar peraturan biasanya Pembina memberikan hukuman yang berhubungan dengan lingkungan, contohnya jika tidak melaksanakna sholat berjamaah maka hukuman anak asuh ialah membersihkan lingkungan panti dan adapun jika anak asuh tidak mengikuti kegiatan gotong royong bersama maka hukumannya dapat bertambah. Tujuan dari pemberian sanksi ini merupakan memberikan efek jera kepada anak asuh sehingga anak asuh tidak mengulangi kesalahan dan pelanggaran tersebut dan membiasakan pada perbuatan-perbuatan yang mencerminkan nilai gotong royong.

Ketiga, upaya Panti Asuhan Taman Bina Insany dengan memberikan pemahaman melalui metode ceramah/penyampaian teori hal ini sering dilakukan ketika setelah selesai sholat berjamaah atau kegiatan bersama lainnya yang disampaikan oleh ketua panti asuhan maupun pengurus panti asuhan lainnya. Setelah mengetahui secara teorinya diharapkan untuk kedepannya dapat di implementasikan dengan baik. Sama halnya dengan metode yang digunakan pada upaya penanaman nilai religius pengurus panti juga menerapkan metode pembiasaan dan keteladanan, namun lebih sering menggunakan metode penyampaian teori/ceramah. Metode pembiasaan tersebut sejalan dengan upaya penerapan aturan ataupun jadwal-jadwal yang sudah dibuat agar anak terbiasa melakukan halhal positif sesuai dengan yang diharapkan. Sedangkan metode keteladanan dilakukan dengan contoh secara langsung oleh pengurus dari ceriman nilai-nilai gotong royong.

Selain itu upaya dalam menanamkan pendidikan karakter pada nilai religius dan gotong royong ini berkerja sama dengan Yayasan Tarbiyah Mazniyah. Adanya hubungan yayasan dan panti memberikan kontrol yang dapat dikoordinasikan ketika anak asuh berada di sekolah maupun setelah berada di Panti Asuhan Taman Bina Insany. Namun meskipun demikian keterlibatan yayasan dengan panti asuhan belum dapat terorganisir dengan baik, khususnya dalam proses penanaman pendidikan karakter. Bentuk kerja sama antara yayasan dan panti asuhan dapat dilihat dari kegiatan-kegiatan keagamaan ataupun gotong royong 
melibatkan/menyesuaikan jadwal antara yayasan dan panti asuhan. Sedangkan evaluasi dilakukan oleh guru-guru melalui nilai afektif di sekolah yang dikoordiasikan dengan panti asuhan.

\section{Pembahasan}

Faktor pendukung dan faktor
penghambat dalam upaya menanamkan
pendidikan karakter pada nilai religius
dan nilai gotong royong. Berdasarkan temuan penelitian dapat diketahui dalam menanamkan Pendidikan karakter di Panti Asuhan Taman Bina Insany pada nilai religius dan nilai gotong royong terdapat faktor pendukung yang mempengaruhi pelaksanaan pendidikan karakter di Panti Asuhan Taman Bina Insany sebagai berikut:

1. Kesediaan dan tekad pengurus panti asuhan

Berdasarkan hasil temuan penelitian adapun tekad dan kemauan pengurus dalam mengembangkan pendidikan karakter pada nilai religius dan nilai gotong royong menjadi salah satu pendukung dalam menanamkan pendidikan karakter pada nilai religius dan nilai gotong royong anak asuh di Panti Asuhan Taman Bina Insany. Dapat dilihat ketika pembina panti asuhan dengan kesabaran dan keteladanan ketika membina anak asuh dalam menanamkan pendidikan karakter nilai religius dan nilai gotong royong.

Hal ini juga dapat lihat dari adanya tujuan panti asuhan dalam menanamkan pendidikan karakter anak asuh yang tertuang dalam visi misi Panti Asuhan Taman Insany Kota Jambi.

2. Komitmen panti asuhan dan anak asuh

Adanya komitmen yang disepakati anak asuh kepada panti asuhan. Komitmen yang dimaksud ialah mengikuti seluruh aturan-aturan panti asuhan dan mengikuti kegiatan yang ada di panti asuhan dan menerima kebijakan yang diberlakukan ketika anak asuh melakukan pelanggaran/kesalahan. Dengan adanya sanksi yang tegas dapat mengontrol atau memelihara perilaku anak asuh agar memiliki karakter yang baik.

Dengan komitmen tersebut dapat mempermudah Panti Asuhan Taman Bina Insany membentuk programprogram dan aturan-aturan yang harus dijalankan anak asuh dalam upaya mengembangkan karakter religius anak asuh. Dan dengan komitmen tersebut panti asuhan memiliki wewenang untuk memberikan sanksi sesuai dengan pelanggaran yang dilakukan. Sanksi/hukuman yang diberikan kepada pelanggar peraturan melalui beberapa tahap sesuai dengan jumlah pelanggaran yang dilakukan, contohnya ketika anak asuh tidak mengikuti kegiatan sholat berjamaah, program tahfidz dan mengaji ataupun terlibat perkelahian, maka sanksi pertama ialah jalan jongkok keliling lapangan panti, membersihkan lingkungan panti ataupun mendapat surat peringatan.

3. Lingkungan sosial yang kondusif

Panti Asuhan Taman Bina Insany memiliki lembaga naungan yaitu Yayasan Tarbiyah Mazniyah. Adanya hubungan yayasan dan panti memberikan kontrol yang dapat dikoordinasikan ketika anak asuh berada di sekolah maupun setelah berada di Panti Asuhan Taman Bina Insany.

Adanya Yayasan Tarbiyah Mazniyah yang berada satu lahan dengan Panti Asuhan Taman Bina Insany dapat memberikan pengaruh positif pada lingkungan sosial Panti Asuhan Taman Bina Insany yang secara tidak langsung perilaku anak asuh ikut terkontrol dengan adanya 
guru-guru di Yayasan Tarbiyah Mazniyah.

Namun adapun kesulitan Panti Asuhan Taman Bina Insany dalam menanamkan pendidikan karakter dipengaruhi oleh faktor-faktor penghambat diantaranya:

1. Kemauan anak yang masih rendah

Dari temuan penelitian yang dilakukan diketahui bahwa anak asuh memiliki kemauan yang rendah untuk mengembangkan nilai religius dan nilai gotong royong, karena dengan tujuan mereka berada di Panti Asuhan Taman Bina Insany ialah memperoleh pengetahuan dari segi kognifnya.

Kemauan anak dalam proses penanaman karakter religius dan gotong royong merupakan salah satu faktor yang dapat menghampat proses penanaman pendidikan karakter yang dilakukan, karena dengan kemauan atau minat anak dapat mengendalikan diri. Namun saat ini di Panti Asuhan Taman Bina Insany kemauan anak dalam mengembangkan karakter pada nilai religius maupun gotong royong

2. Background anak asuh yang heterogen

Background/latar belakang anak merupakan salah satu faktor penghambat/penyebab sulitnya dalam proses penanaman pendidikan karakter di Panti Asuhan Taman Bina Insany. Latar belakang yang dimaksud disini ialah asal daerah anak asuh, yang mana di Panti Asuhan Taman Bina Insany rata-rata anak asuh berasal dari berbagai daerah dusun. Sehingga penggunaan nada, bahasa dan perilaku antar anak sering kali terjadi kesalahpahaman. Dan adapun anak asuh yang merupakan dari broken home/perpisahan orang tua, yatim, piatu, yatim piatu sehingga dalam proses penanaman pendidikan karakter pada setiap anak sebenarnya tidak dapat disamakan.
3. Kurangnya sarana prasarana dan SDM di Panti Asuhan Taman Bina Insany.

Mengenai sarana dan prasarana sebagai media penujung pelaksanaan pendidikan karakter di Panti Asuhan Taman Bina Insany masih belum terpenuhi. Keterbatasan ini tentu juga mempengaruhi terlaksananya pendidikan karakter di Panti Asuhan Taman Bina Insany. Panti Asuhan Taman Bina Insany memiliki masjid/aula, asrama putri yang berada di bawah masjid/aula, asrama putra yang berada di atas masjid/aula, satu kamar mandi anak asuh putri, satu toilet dan satu tempat mandi terbuka untuk anak asuh putra yang berada tepat didepan asrama putri. Dengan keterbatasan fasilitas ini mengakibatkan terhambatnya penanaman pendidikan karakter nilai religius maupun gotong royong, seperti salah satunya sering terjadinya keributan antrian mandi.

Dan kurangnya SDM di Panti Asuhan Taman Bina Insany yang memiliki satu Pembina yang turun langsung membersamai anak asuh, dengan jumlah anak yang banyak dan jumlah pembina terbatas untuk mengontrol seluruh kegiatan anak asuh sehingga tata tertib dan jadwal maupun peraturan tidak dapat di laksanakan dengan konsisten. Diketahui juga Pembina anak asuh berada di Panti Asuhan dari pukul 05.00-21.00 WIB, sedangkan dalam Undang-Undang No 30 Tahun 2011 tentang Standar Nasional Pengasuhan Lembaga Kesejahteraan Sosial Anak dijelaskan bahwa pengasuhan oleh anak asuh dilakukan dalam rentang waktu 24 jam.

4. Kurangnya perencanaan kerja sama yang matang antara yayasan dan panti asuhan dalam pelaksanaan pendidikan kakrakter 
Kedudukan panti asuhan asuhan yang merupakan naungan dari yayasan tarbiyah mazniyah seharusnya menjadi salah satu potensi yang sangat baik dalam pelaksanaan pendidikan karakter kepada anak asuh. Bentuk keterlibatan dan kerja sama yang dilakukan yayasan dan panti asuhan melalui kegiatan-kegiatan yang dilakukan secara terkoordinasi, contohnya dalam kegiatan sholat berjamaah maupun kegiatan gotong royong yang dilakukan serta adanya bentuk evaluasi secara umum yang dilakukan oleh masing-maisng guru Yayasan Tarbiyah Mazniyah mengenai karakter anak asuh.

Namun dalam pelaksanaan pendidikan karakter perlu adanya perencanaan, pelaksanaan dan evalusi yang terarah sehinnga dalam proses penanaman pendidikan karakter dapat dilakukan secara maksimal. Kerja sama antara yayasan dan panti asuhan belum ada perencanaan yang terstruktur dan terarah. Dan masih adanya pandangan yang memisahkan anatara tugas panti asuhan dan yayasan.

\section{KESIMPULAN}

Berdasarkan hasil penelitian dan pembahasan mengenai Peran panti asuhan dalam menanamkan pendidikan karakter pada nilai religius dan gotong royong anak asuh dengan memberikan pelayanan kuratif dan rehabilitive berupa bimbingan, perbaikan/pemulihan terhadap masalah karakter anak asuh dan pengembalian hakhak anak untuk memperoleh kedudukan serta perannya agar dapat berkembang secara wajar. Salah Satunya dengan memberikan pelayanan pendidikan formal memberikan peluang pada anak untuk bersekolah pada tingkat SLTA dan SLTP agar anak asuh dapat lebih memahami esensi pengembangan karakter lebih luas, yang mana Panti Asuhan Taman Bina
Insany merupakan naungan dari Yayasan Tarbiyah Mazniyah.

Bimbingan dan upaya dalam penanaman pendidikan karakter pada nilai religius dan nilai gotong royong berupa pertama, pada nilai religius panti asuhan memberikan bentuk kegiatan/program tahfidz, 3S (Salam, Senyum, Sapa) dan sholat berjamaah, muhadarah. Sedangkan pada pelaksanaan nilai gotong royong dilakukan sehari-hari dalam menjalankan tugas piket dan aturan-aturan untuk membentuk karakter kooperatif/kerja sama, komunikatif, sosialisasi/ persahabatan dan tolong menolong. Kedua, Memberikan pemahaman/ pengetahuan mengenai nilai religius dan nilai gotong royong dengan metode ceramah, pembiasaan dan teladan. Ketiga, memberikan aturan hukum atau sanksi untuk mendidik dan mendisiplinkan anak asuh dalam upaya penanaman pendidikan karakter pada nilai religius dan gotong royong.

Sehingga dalam upaya penanaman pendidikan karakter pada nilai religius dan nilai gotong royong didukung oleh kesediaan dan tekad pengurus panti asuhan, komitmen anak asuh dengan panti asuhan dan lingkungan sosial yang kondusif. Namun dengan upaya dan faktor pendukung yang ada, kesulitan dalam melaksanakan pendidikan karakter di Panti Asuhan Taman Bina Insany juga dipengaruhi oleh beberapa faktor penghambat yaitu kemauan anak yang masih rendah, background anak yang heterogen, kurangnya sarana prasarana dan SDM (Sumber Daya Manusia), kurangnya perencanaan kerja sama yang matang antara panti asuhan dengan yayasan dalam pelaksanaan pendidikan karakter.

Dalam penelitian ini peneliti hanya memfokuskan pada nilai religius dan nilai gotong royong saja, bagi peneliti selanjutnya diharapkan dapat mengkaji keseluruhan nilai-nilai karakter yang ada, 
karena 5 nilai utama yang dirumuskan

memiliki keterikatan satu sama lain.

pada program penguatan karakter

\section{DAFTAR PUSTAKA}

Abdullah Sani, Ridwan. 2016. Pendidikan karakter. Jakarta. PT Bumi Aksara.

Abidin, Mustika. 2018. Peran panti asuhan membentuk karakter disiplin dalam meningkatkan kecerdasan intrapersonal anak. An-nisa', 11(1), 357.

Arikunto, Suharsismi. 2010. Manajemen penelitian. Jakarta: Rineka Cipta.

Arikunto, Suharsismi. 2013. Prosedur penelitian suatu pendekatan praktik. Jakarta: Rineka Cipta.

Aziz, Hamka Abdul. 2012. Pendidikan karakter berpusat pada hati. Jakarta Selatan: Almawardi Prima.

Creswell. 2015. Penelitian kualitatif \& desain riset. Yogyakarta: Pustaka Pelajar.

Dewantara, J. A., \& Nurgiansah, T. H. (2021a). Peningkatan Keaktifan Belajar Melalui Penerapan Model Picture And Picture Dalam Pembelajaran PPKn di Sekolah Dasar. Jurnal Publikasi Pendidikan, 11(3), 234-241.

Dewantara, J. A., \& Nurgiansah, T. H. (2021b). Strengthening Pancasila Values During the Covid-19 Pandemic. Edukatif: Jurnal Ilmu Pendidikan, 3(4), 2411-2417.

Helmawati. 2017. Pendidikan Karakter Sehari-hari. Bandung: PT Remaja Rosdakarya.

Hikmah, Barokatun. 2020. Peran Pengasuh Dalam Membentuk Karakter Religius Pada Anak Yatim Di Panti Asuhan Baiturrahman Jambi. Fakultas Dakwah Universitas Islam Negeri Sultas Thaha Saifuddin Jambi.

J. Maleong, Lexy. 2014. Metode Penelitian Kualitatif. Bandung: PT remaja Rosdakarya.

Kurniawan, Syamsul. 2017. Pendidikan Karakter: Konsepsi \& Implementasi Secara Terpadu di Lingkungan Keluarga, Sekolah, Perguruan Tinggi, Dan Masyarakat. Yogyakarta: Ar-Ruzz Media.

Lestari, Winda Anggunita. 2016. Peran lembaga kesejahteraan sosial dalam menanamkan pendidikan karakter terhadap anak asuh dipanti asuhan. Jurnal civic hukum, 1(2), 84-85.

Maibang, Suci Wahyuninta. 2017. Peran Panti Asuhan Puteri 'Aisyiyah Dalam Mengembangkan Kreativitas Anak. Program Pengembangan Masyarakat Islam. Fakultas Dakwah Dan Komunikasi Universitas Islam Negeri Sumatera Utara.

Makmun, Abin Syamsuddin. 2007. Psikologi Pendidikan. Bandung: PT Remaja.

Mu'in, Fatchul. 2014. Pendidikan Karakter konstruksi Teoritik \& Praktik. Jogjakarta: Ar-Ruzz Media.

Ni'mah, Siti Kholisotun. 2016. Pemenuhan Hak Anak Di Panti Asuhan Nurul Falah Jemur Wonosari Surabaya. Al-Qanun, 19(1), 34-36.

Nurgiansah, T. H. (2020). Pelatihan Penulisan Artikel Ilmiah Bagi Mahasiswa PPKn Universitas PGRI Yogyakarta. JNPM: Jurnal Nasional Pengabdian Masyarakat, 1(1), 16-23.

Nurgiansah, T. H. (2021a). Partisipasi Politik Masyarakat Sleman di Masa Pandemi Covid-19 dalam Konteks Pendidikan Kewarganegaraan. Jurnal Civic Hukum, 6(1), 1-9.

Nurgiansah, T. H. (2021b). Pemanfaatan E-Learning Dalam Pembelajaran Pendidikan Kewarganegaraan. JINTECH: Journal of Information Technology, 2(2), 138-146.

Peraturan Menteri Sosial Republik Indonesia Nomor 30 Tahun 2011 tentang Standar Nasional Pengasuhan Anak Kesejahteraan Sosial Anak. Jakarta: KEMENSOS.

Rachman, F., Nurgiansah, T. H., \& Kabatiah, M. (2021). Profilisasi Pendidikan Kewarganegaraan dalam Kurikulum Pendidikan Indonesia. Edukatif: Jurnal Ilmu Pendidikan, 3(5), 2970-2984.

Sakinah, R. N., \& Dewi, D. A. (2021). Implementasi Nilai-Nilai Pancasila Sebagai Karakter Dasar 
Para Generasi Muda Dalam Menghadapi Era Revolusi Industrial 4.0. Jurnal Kewarganegaraan, 5(1), 152-167.

Samrin. 2016. Pendidikan Karakter (Sebuah Pendekatan Nilai). Al-Ta'dib, 09(1).

Sjarkawi. 2006. Pembentukan Kepribaddian Anak. Jakarta: Bumi Aksara.

Sugiyono. 2012. Penelitian Kuantitatif, kualitatif, dan R\&D. Bandung: Alfabeta CV.

Sugiyono. 2015. Memahami Penelitian Kualitatif. Bandung: Alfabeta. CV.

Sumadi, Eko. 2018. Anomali Pendidikan Karakter. Jurnal Tarbawi, 15(2), 25.

Surhadi, didik dkk. 2017. Konsep dan Pedoman Penguatan Pendidikan Karakter. Jakarta: Sekretariat TIM PKK Kemendikbud.

Syarbini, Amirulloh. 2016. Pendidikan Karakter Berbasis Keluarga. Jogjakarta. Ar-Ruzz.

Tim penyususn Penilaian Pendidikan. 2019. Model Pendidikan Karakter. Jakarta: Pusat Penilian Karakter.

Undang-Undang Nomor 87 Tahun 2017 tentang Penguatan Pendidikan Karakter

Yuliana, E. Dewi. 2010. Pentingnya Pendidikan Karakter Bangsa Guna Merevitalisasi Ketahanan Bangsa. Udayana Mengabdi, 9(2), 92-100.

Zubaedi. 2011. Desain Pendidikan Karakter. Jakarta: kencana predana media. 